\title{
Ectoparasitic fauna in freshwater ornamental fish acquired by a wholesaler in the city of São Paulo
}

\section{Fauna ectoparasitária em peixes ornamentais de água doce adquiridos por estabelecimento distribuidor na cidade de São Paulo}

\author{
Pedro Henrique Magalhães CARDOSO ${ }^{1}$; Arthur Roberto da $\operatorname{COSTA}^{1}$; Simone de Carvalho BALIAN ${ }^{1}$ \\ ${ }^{1}$ Universidade de São Paulo, Faculdade de Medicina Veterinária e Zootecnia, Departamento \\ de Medicina Veterinária Preventiva e Saúde Animal, São Paulo - SP, Brazil
}

\begin{abstract}
This study analyzed the ectoparasitic fauna of freshwater ornamental fish marketed by a wholesaler in the São Paulo city. This study was undertaken from January to December 2016. A total of 268 freshwater ornamental fishes of various species that showed signs of disease after arrival at the establishment were evaluated. From the individuals, ectoparasites were collected by scraping off the skin and gills and visualized using an optical microscope at increasing magnification of 40x, 100x, 200x, and 400x. Parasites were found in 220 animals (82\%); 11 different parasites were recorded, which included Ichthyophthirius multifiliis, Monogenes, Metacercariae (Centrocestus formosanus), Epistylis spp., Chilodonella spp., Lernaea spp., Tetrahymena spp., Piscinoodinium spp., Trichodina spp., Ichthyobodo spp. and Argulus spp. The occurrence of the parasites in the establishment studied can indicates that the suppliers' lack of good sanitary and hygiene practices in the management of their facilities, consequently distributing infested animals and putting the whole supply chain at risk.
\end{abstract}

Keywords: Ornamental fish. Ectoparasitic fauna. Diseases. Animal health.

\section{Resumo}

O presente trabalho analisou a fauna ectoparasitária de peixes ornamentais de água doce comercializados em um estabelecimento atacadista de peixes ornamentais na grande São Paulo no período de janeiro a dezembro de 2016. Foram avaliados 268 peixes ornamentais de água doce de diversas espécies que apresentaram sinais de doença após a chegada ao estabelecimento. Nos indivíduos foi efetuada a pesquisa de ectoparasitas por meio da raspagem de pele e brânquias e visualização em microscópio óptico em aumento 40x, 100x, 200x e 400x. Foram encontrados parasitos em 220 animais (82\%) incluindo 11 parasitos distintos: Ichthyophthirius multifiliis, Monogêneas, Metacercárias (Centrocestus formosanus), Epistylis spp., Chillodonella spp., Lernaea spp., Tetrahymena spp., Piscinoodinium spp., Trichodina spp., Ichthyobodo spp. e Argulus spp. A ocorrência dos parasitas no estabelecimento em estudo pode ser indicativa da falta de boas práticas sanitárias e de higiene dos fornecedores no manejo de suas instalações e, consequentemente, na distribuição de animais infestados, o que coloca em risco toda cadeia.

Palavras-chave: Peixes ornamentais. Fauna ectoparasitária. Doenças. Saúde animal.

Correspondence to:

Pedro Henrique Magalhães Cardoso

Universidade de São Paulo, Faculdade de Medicina Veterinária

e Zootecnia, Departamento de Medicina Veterinária

Preventiva e Saúde Animal

Av. Prof. Dr. Orlando Marques de Paiva, 87 - Cidade

Universitária

CEP 05508-270, São Paulo, SP, Brazil

e-mail: pedrohenriquemedvet@usp.br

Received: 03/05/2018

Approved: 03/09/2018

\section{Introduction}

The ornamental aquarium fish constitutes a large segment of the pet industry in which the United States, Europe, and Japan make up the bulk of the market (NOGA, 2010). Brazil holds the second place in the world market for pets. In 2016, it was valued at $\mathrm{R} \$ 18.9$ billion, according to the Brazilian Institute of Geography and Statistics. Fish are the fourth most common pet species in Brazil, behind dogs, cats and birds, and accounts for about 18 million units according to the latest survey (ABINPET, 2017). 
Around the world, there are 4000 and 5000 ornamental freshwater fish species (of which about $90 \%$ are already cultivated) and over 1450 ornamental marine species, most of which are extracted from nature (WHITTINGTON; CHONG, 2007). Most ornamental fish traded in Brazil are cultivated on fish farms. In Brazil, the Minas Gerais state is the largest producer and supplies part of the market in the Northeast, Midwest, Southeast, and South of the country (MAGALHÃES; JACOBI, 2013). The Amazon state has the greatest diversity of ornamental fishes, with a predominance of extractivism. The Amazon state contributes about $93 \%$ to the Brazilian ornamental fish exports, which is an important economic activity that generates employment and income for a part of the population (ANJOS et al., 2009).

The trade and movement of live animals without standardized and safe technical procedures increases the risk of numerous agents that cause infectious diseases and serious health problems to spread, especially in poor regions (WHITTINGTON; CHONG, 2007; PEELER; FEIST, 2011; MCDERMOTT; PALMEIRO, 2013).

Animals are often exposed to excessive handling and crowding in transport (DAVIS et al., 2002), which increases the concentration of metabolic residues (mainly ammonia) in water, leading to animal intoxication and stress. Stress has inhibitory effects on the immune system and favors the onset of opportunistic diseases such as some parasites (FRANCIS-FLOYD, 2012). Animals often live in harmony with the pathogenic agents, but as soon as an imbalance occurs, as in the immunity of the host, the latter proliferate, causing diseases (CARDOSO et al., 2017a, 2017b). This study aimed to evaluate animals that presented clinical signs compatible with ectoparasitic disease after they were transported to an ornamental fish wholesaler located in São Paulo city.

\section{Materials and Methods Study Animals}

The place chosen for the study was a wholesale shop located in the Sao Paulo city that receive animals from different parts of Brazil to distribute to all Brazilian states. The volume of animals traded weekly is around fifty thousands of fresh and marine fishes.

Materials were collected from January to December 2016. The species chosen for the study were those with high history of mortality in the establishment, and the animals used were those with apathy and clinical signs of the disease.
Skin scrapings and gills from 268 fresh water fishes of different species were analyzed.

\section{Sample Collection}

Moribund animals were treated with an anesthetic solution of Eugenol - $75 \mathrm{mg} / \mathrm{L}$ of clove oil (ROUBACH et al., 2005) diluted in a 4-liter container for 40 to 60 minutes and then euthanized by the spinal cord section technique (NOGA, 2010). Once euthanized, the fish skin and gills were scraped with a scalpel. This study was approved by Ethics Committee, under number CEUA N 4543160516.

\section{Sample Analysis}

For the analysis of the samples collected by scraping, a drop of water was deposited on the slide to facilitate the observation of the movement of the ectoparasites under the microscope cover slip (NOGA, 2010; MARTINS et al., 2015). The material was analyzed under an optical microscope at increasing magnifications of $40 \times, 100 \times$, $200 \times$, and $400 \times$.

\section{Results and Discussion}

Among the 268 individuals examined under the microscope, 215 (80.22\%) showed infection by ectoparasites. (Table 1).

Table 1 - Parasites found in ornamental fish were evaluated. Only presence ( 1 parasite) or absence ( 0 parasites) was noted. The study was undertaken at the Department of Preventive Veterinary Medicine and Animal Health, Faculty of Veterinary Medicine and Animal Science, University of São Paulo - USP, São Paulo (SP) in 2017

\begin{tabular}{ccc}
\hline Agent & No. of fish infected & \% of parasites \\
\hline Ichthyophthirius multifiiis & 75 & 34.091 \\
Metacercariae & 40 & 18.182 \\
Monogenea & 38 & 17.273 \\
Epistylis spp. & 24 & 10.909 \\
Chilodonella spp. & 11 & 5.000 \\
Lernaea spp. & 10 & 4.545 \\
Tetrahymena spp. & 6 & 2.727 \\
Piscinoodinium spp. & 5 & 2.273 \\
Trichodina spp. & 5 & 2.273 \\
Ichthyobodo spp. & 4 & 1.818 \\
Argulus spp. & 2 & 0.909 \\
\hline TOTAL PARASITES & 220 & - \\
\hline ANIMALS INFECTED & 215 & 80.224 \\
\hline TOTAL ANIMALS & 268 & \\
\hline
\end{tabular}


Ichthyophthirius multifiliis causes the white spot disease (Figure 1a). When analyzed, they present a horseshoeshaped nucleus easily recognizable (Figure $1 \mathrm{~b}$ ). This parasite species causes the most trouble for hobbyists around the world (TAVARES-DIAS et al., 2010; IQBAL; HAROON, 2014; ADEL et al., 2015; SAHA; BANDYOPADHYAY, 2017). The disease is easily identified through clinical signs and microscopy of the scraping of the affected area. A single parasite gives rise to hundreds of others that are ready to infect new hosts, and consequently they spread quickly. Overcrowded aquariums are mainly affected. This parasite can lead to high mortality rates. When diagnosed early and treated, recovery is successful with reduced losses (FRANCIS-FLOYD et al., 2009; VON GERSDORFF JØRGENSEN, 2016).
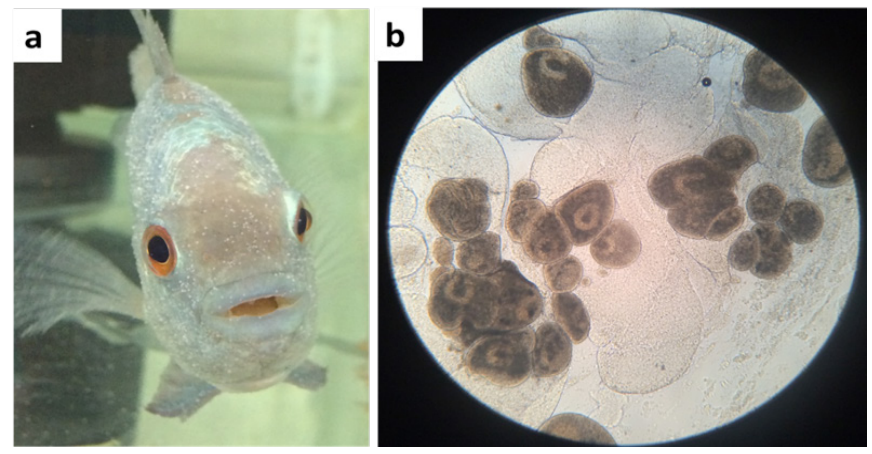

Figure 1 - (a) White spot disease, caused by the protozoan Ichthyophthirius multifilis in the ornamental fish Amphilophus trimaculatus; (b) The mature parasite under $200 \times$ magnification showing the horseshoeshaped core - photo by CARDOSO, PEDRO HENRIQUE MAGALHÃES

Other protozoan ectoparasites prevalent at the study site include Ichthyobodo spp., Epistylis spp., Chilodonella spp., Tetrahymena spp., Piscinoodinium spp., Trichodina spp., which are frequently reported from other studies across the world (THILAKARATNE et al., 2003; TAVARES-DIAS et al., 2010; IQBAL; HAROON, 2014; SAHA; BANDYOPADHYAY, 2017). They are almost frequently associated with aquatic environments with low water quality, high concentration of organic matter, and inefficient sanitary management. These parasites infest debilitated hosts, causing intense stress, serious injury, leading to death, with significant economic losses (MARTINS et al., 2015).

Many of the fishes analyzed (Figure 2a) presented metacercariae in their gills, (Figure $2 \mathrm{~b}$ ) suggestive of the parasite Centrocestus sp. The life cycle of this parasite requires a snail as a transport host. Good management practices that prevent molluscs from entering the system are sufficient to control them. Fishes with high infestations by encapsulated metacercariae in the gills presented respiratory deficiency and panting behavior (MEHRDANA et al., 2014). Among the fishes that had metacercariae, $38 \%$ were of the species Xiphophorus maculatus, whose farmer reported the presence of snails and other animals including birds, insects, amphibians, and mammals in the property, which implied a lack of sufficient sanitation at this facility.

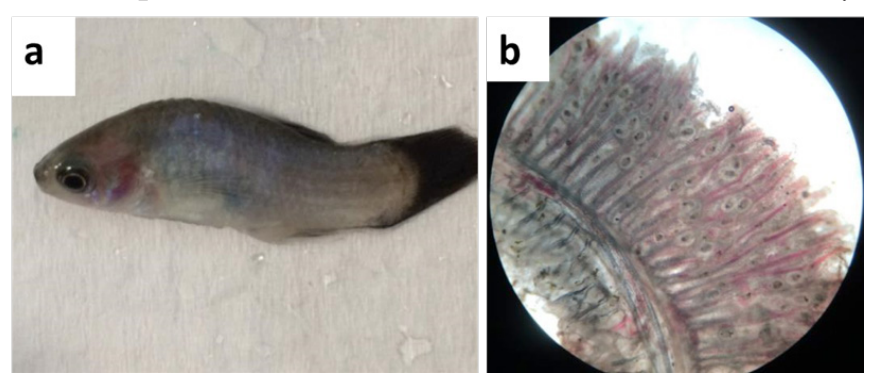

Figure 2 - (a) Xiphophorus maculatus, which was very weak and breathless; (b) The presence of metacercariae (shown at $40 \times$ magnification) suggests Centrocestus sp. in the gills - photo by CARDOSO, PEDRO HENRIQUE MAGALHÃES

Species of the class Monogenea are also importance parasites affecting freshwater fishes. The most frequent genera are Dactylogyrus and Gyrodactylus. These parasites have hooks (Figure $3 b$ ) that attach to the skin tissues (Figure 3a) and gills of the host, causing lesions that open doors for secondary bacterial infections (REED et al., 2012; CARDOSO et al., 2017b). Other parasites found less frequently were Lernaea, Piscinoodinium, and Argulus.

In addition to parasitizing fishes, the crustaceans Lernaea (Figures $4 \mathrm{a}$ and $4 \mathrm{~b}$ ) and Argulus (Figures $4 \mathrm{c}$ and $4 \mathrm{~d}$ ) also cause lesions that may serve as a gateway for secondary bacterial infections and disseminate viral diseases (STECKLER; YANONG, 2012a, 2012b). Piscinoodinium is a parasite without any specific host, which is responsible for significant sanitary problems in Brazil in freshwater fishes, according to producers. Intense infestations cause high mortality rates (MARTINS et al., 2015) if not treated early on.

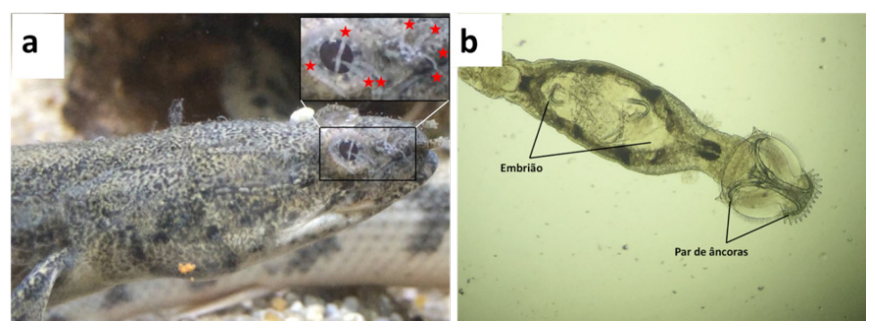

Figure 3 - (a) Polypterus palmas with Monogenes on the skin and ocular region; (b) parasite (shown at $40 \times$ magnification) suggests Gyrodactylus spp. - photo by CARDOSO, PEDRO HENRIQUE MAGALHÃES 

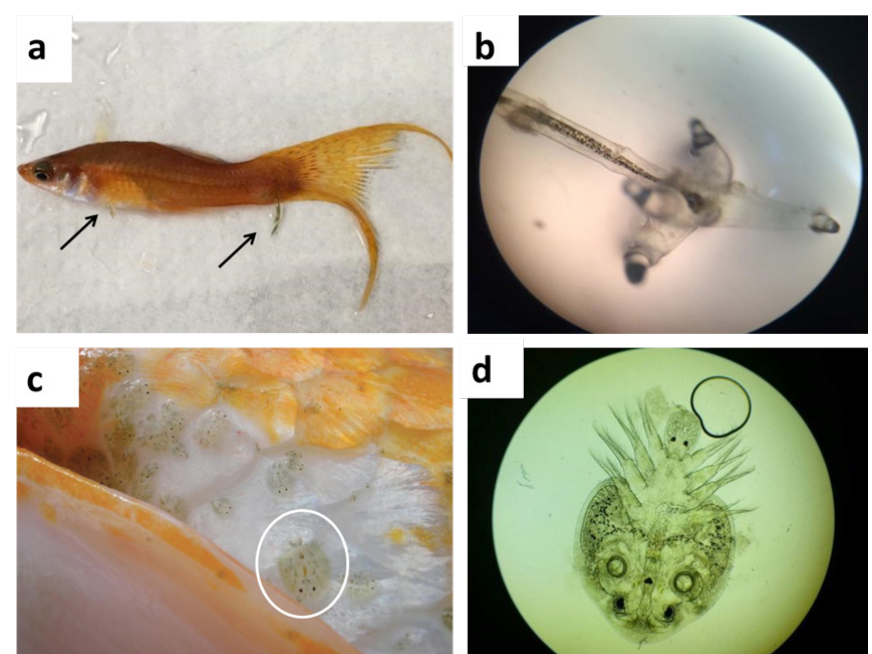

Figure 4 - (a) Lernaea spp. (arrow) parasitizing Xiphophorus hellerii; (b) $40 \times$ magnification of the anchor-shaped hooks that help to attach to the skin of the fish can be seen; (c) Argulus spp. parasitizing Cyprinus carpio; (d) Argulus spp. under $4 \times$ magnification. - photo by CARDOSO, PEDRO HENRIQUE MAGALHÃES CARDOSO

The complete list of species examined is presented in Table 2.

Table 2 - Species of fish evaluated in this study. This study was undertaken at the Department of Preventive Veterinary Medicine and Animal Health, Faculty of Veterinary Medicine and Animal Science, University of São Paulo - USP, São Paulo (SP) in 2017

\begin{tabular}{|c|c|c|c|}
\hline Species & $\begin{array}{c}\text { No. of } \\
\text { animals } \\
\text { examined }\end{array}$ & Species & $\begin{array}{c}\text { No. of } \\
\text { animals } \\
\text { examined }\end{array}$ \\
\hline $\begin{array}{l}\text { Aequidens } \\
\text { rivulatus }\end{array}$ & 3 & $\begin{array}{l}\text { Metynnis } \\
\text { maculatus }\end{array}$ & 1 \\
\hline $\begin{array}{l}\text { Amphilophus } \\
\text { citrinellus }\end{array}$ & 1 & $\begin{array}{c}\text { Mikrogeophagus } \\
\text { altispinosus }\end{array}$ & 7 \\
\hline $\begin{array}{l}\text { Amphilophus } \\
\text { trimaculatus }\end{array}$ & 4 & $\begin{array}{l}\text { Mikrogeophagus } \\
\text { ramirezi }\end{array}$ & 4 \\
\hline Arapaima gigas & 1 & $\begin{array}{c}\text { Misgurnus } \\
\text { anguillicaudatus }\end{array}$ & 1 \\
\hline $\begin{array}{l}\text { Astronotus } \\
\text { ocellatus }\end{array}$ & 3 & $\begin{array}{c}\text { Moenkhausia } \\
\text { sanctaefilomenae }\end{array}$ & 1 \\
\hline $\begin{array}{c}\text { Aulonocara } \\
\text { hansbaenschi }\end{array}$ & 1 & $\begin{array}{c}\text { Monodactylus } \\
\text { argenteus }\end{array}$ & 1 \\
\hline $\begin{array}{l}\text { Baryancistrus } \\
\text { spp. }\end{array}$ & 2 & $\begin{array}{l}\text { Myloplus } \\
\text { rubripinnis }\end{array}$ & 2 \\
\hline Betta splendens & 6 & $\begin{array}{c}\text { Nandopsis } \\
\text { octofasciatum }\end{array}$ & 1 \\
\hline $\begin{array}{l}\text { Carassius } \\
\text { auratus }\end{array}$ & 31 & $\begin{array}{c}\text { Nematobrycon } \\
\text { palmeri }\end{array}$ & 1 \\
\hline $\begin{array}{c}\text { Carnegiella } \\
\text { strigata }\end{array}$ & 2 & Notopterus chitala & 1 \\
\hline $\begin{array}{l}\text { Chromobotia } \\
\text { macracanthus }\end{array}$ & 2 & $\begin{array}{l}\text { Osteoglossum } \\
\text { bicirrhosum }\end{array}$ & 1 \\
\hline Cichla ocellaris & 1 & Otocinclus spp. & 1 \\
\hline
\end{tabular}

\begin{tabular}{|c|c|c|c|}
\hline Species & $\begin{array}{c}\text { No. of } \\
\text { animals } \\
\text { examined }\end{array}$ & Species & $\begin{array}{c}\text { No. of } \\
\text { animals } \\
\text { examined }\end{array}$ \\
\hline $\begin{array}{l}\text { Cichlasoma } \\
\text { maculicauda }\end{array}$ & 1 & $\begin{array}{l}\text { Paracheirodon } \\
\text { spp. (2 species) }\end{array}$ & 4 \\
\hline $\begin{array}{l}\text { Cichlasoma } \\
\text { octofasciatum }\end{array}$ & 2 & Parambassis ranga & 1 \\
\hline $\begin{array}{l}\text { Cichlasoma } \\
\text { salvini }\end{array}$ & 4 & $\begin{array}{c}\text { Piaractus } \\
\text { mesopotamicus }\end{array}$ & 1 \\
\hline $\begin{array}{l}\text { Cichlasoma } \\
\text { severum }\end{array}$ & 4 & Poecilia latipinna & 3 \\
\hline Cyprinus carpio & 9 & Poecilia reticulata & 15 \\
\hline Corydora elegans & 5 & Poecilia sphenops & 3 \\
\hline Danio rerio & 4 & Polypterus palmas & 1 \\
\hline $\begin{array}{l}\text { Etroplus } \\
\text { maculatus }\end{array}$ & 3 & $\begin{array}{l}\text { Pseudacanthicus } \\
\text { leopardus }\end{array}$ & 1 \\
\hline $\begin{array}{c}\text { Gymnocorymbus } \\
\text { ternetzi }\end{array}$ & 7 & $\begin{array}{c}\text { Pseudotropheus } \\
\text { demasoni }\end{array}$ & 1 \\
\hline $\begin{array}{c}\text { Hemigrammus } \\
\text { ulreyi }\end{array}$ & 1 & $\begin{array}{l}\text { Pterophyllum } \\
\text { scalare }\end{array}$ & 20 \\
\hline $\begin{array}{l}\text { Helostoma } \\
\text { temminckii }\end{array}$ & 3 & $\begin{array}{l}\text { Puntigrus } \\
\text { tetrazona }\end{array}$ & 1 \\
\hline $\begin{array}{l}\text { Hemiancistrus } \\
\text { inspector }\end{array}$ & 3 & Puntius titteya & 1 \\
\hline $\begin{array}{l}\text { Hemichromis } \\
\text { bimaculatus }\end{array}$ & 2 & $\begin{array}{c}\text { Pygocentrus } \\
\text { nattereri }\end{array}$ & 1 \\
\hline Heros severus & 1 & $\begin{array}{l}\text { Symphysodon } \\
\text { aequifasciatus }\end{array}$ & 2 \\
\hline $\begin{array}{l}\text { Hypancistrus } \\
\text { spp. }\end{array}$ & 2 & $\begin{array}{l}\text { Symphysodon } \\
\text { discus }\end{array}$ & 10 \\
\hline $\begin{array}{l}\text { Hyphessobrycon } \\
\text { spp. (4 species) }\end{array}$ & 10 & $\begin{array}{l}\text { Tanichthys } \\
\text { albonubes }\end{array}$ & 2 \\
\hline $\begin{array}{l}\text { Hypostomus } \\
\text { cochliodon }\end{array}$ & 1 & $\begin{array}{l}\text { Trichopodus spp. } \\
\text { (4 species) }\end{array}$ & 18 \\
\hline $\begin{array}{c}\text { Hypselecara } \\
\text { coryphaenoides }\end{array}$ & 1 & $\begin{array}{c}\text { Uaru } \\
\text { amphiacanthoides }\end{array}$ & 1 \\
\hline Iriatherina spp. & 1 & Xenotilapia spp. & 1 \\
\hline $\begin{array}{c}\text { Labeo } \\
\text { chrysophekadion }\end{array}$ & 1 & $\begin{array}{l}\text { Xiphophorus } \\
\text { hellerii }\end{array}$ & 8 \\
\hline $\begin{array}{c}\text { Macropodus } \\
\text { opercularis }\end{array}$ & 1 & $\begin{array}{c}\text { Xiphophorus } \\
\text { maculatus }\end{array}$ & 24 \\
\hline $\begin{array}{l}\text { Melanotaenia } \\
\text { spp. (3 species) }\end{array}$ & 4 & & \\
\hline TOTAL & & 268 & \\
\hline
\end{tabular}

Carassius auratus, Xiphophorus maculatus, Pterophyllum scalare, Trichopodus spp., and Poecilia reticulata (together responsible for $40.30 \%$ of the animals examined) showed parasite infestation. However, additional studies with a higher number of fish of species with clinical signs are required to verify whether the disease is caused by parasitism or another infectious disease.

\section{Conclusion}

The occurrence of the aforementioned parasites in the establishment under study can indicate the suppliers' lack 
of good sanitary and hygiene practices in the management of their facilities, consequently distributing infested animals and putting the whole supply chain at risk. This causes losses, with the death of animals and increased medical expenditure to treat infected animals.

These findings highlight the need for intensifying a system of good practices of health management at the suppliers' facility, such as: identification of parasites at source and adequate measures to treat, control or avoid parasite outbreaks before sending fishes. This would

\section{References}

ADEL, M.; GHASEMPOUR, F.; AZIZI, H. R.; SHATERI, M. H.; SAFIAN, A. R. Survey of parasitic fauna of different ornamental freshwater fish species in Iran. Veterinary Research Forum, v. 6, n. 1, p. 75-78, 2015. Available from: <https://www.ncbi.nlm.nih.gov/pubmed/25992255>. Viewed: Dec. 17th, 2018.

ANJOS, H. D. B.; AMORIM, R. M. S.; SIQUEIRA, J. A.; ANJOS, C. R. Exportação de peixes ornamentais do estado do Amazonas, Bacia Amazônica, Brasil. Boletim do Instituto de Pesca, v. 35, n. 2, p. 259-274, 2009. Available from: <https://www.pesca.sp.gov.br/35_2_259-274.pdf>. Viewed: Dec. 17th, 2018.

ASSOCIAÇÃO BRASILEIRA DA INDÚSTRIA DE PRODUTOSPARAANIMAISDEESTIMAÇÃO-ABINPET. Dados de Mercado. 2017. Available from: https://bit. ly/2R8Fdta. Viewed: Dec. 17th, 2018.

CARDOSO, P. H. M.; BALIAN, S. C.; MATUSHIMA, E. R.; PÁDUA, S. B.; MARTINS, M. L. First report of scuticociliatosis caused by Uronema sp: in ornamental reef fish imported into Brazil. Brazilian Journal of Veterinary Parasitology, v. 26, n. 4, p. 1-6, 2017a. doi: 10.1590/S1984-29612017031.

CARDOSO, P. H. M.; COSTA, A. R.; PESTELli, M.; BALIAN, S. C. Relato de caso de parasitismo por monogênea no peixe ornamental Polypterus palmas no Brasil. Revista de Educacão Continuada do CRMV-SP, v. 15, n. 1, p. 30-36, 2017b. Available from: <https://www. revistamvez-crmvsp.com.br/index.php/recmvz/article/ view/36763>. Viewed: Dec. 17th, 2018. be possible with the presence of a qualified veterinary professional in these facilities to provide technical guidance.

\section{Acknowledgements}

We thank the company Ipiranga Peixes Ornamentais from which we procured the ornamental fishes for this study for kindly donating the animals.

\section{Conflict of Interest}

There is no conflict of interest

DAVIS, K. B.; GRIFFIN, B. R.; GRAY, W. L. Effect of handling stress on susceptibility of channel catfish Ictalurus punctatus to Ichthyophthirius multifiliis and channel catfish virus infection. Aquaculture, v. 214, n. 1-4, p. 55-66, 2002. doi: 10.1016/S0044-8486(02)00362-9.

FRANCIS-FLOYD, R. Stress: its role in fish disease. IFAS Extension University of Florida, v. CIR919, p. 1-4, 2012. Available from: $<$ http://edis.ifas.ufl.edu/fa005 $>$. Viewed: Dec. 17th, 2018.

FRANCIS-FLOYD, R.; YANONG, R.; POUDER, D. Ichthyophthirius multifiliis (White Spot) infections in fish. IFAS Extension University of Florida, v. CIR920, p. 1-5, 2009. Available from: <http://edis.ifas.ufl.edu/fa006>. Viewed: Dec. 17th, 2018.

IQBAL, Z.; HAROON, F. Parasitic infections of some freshwater ornamental fishesimported in Pakistan. Pakistan Journal Zoology, v. 46, n. 3, p. 651-656, 2014. Available from: <http://zsp.com.pk/pdf46/651-656\%20_8_\%20 PJZ-1661-14\%20\%2016-4-14\%20Parasitic\%20fauna\%20 of\%20five\%20ornamental\%20fishes[1][1][1].pdf>. Viewed: Dec. 17th, 2018.

MAGALHÃES, A. L. B.; JACOBI, C. M. Reprodução do peixe não-nativo Barbo-Rosado Pethia conchonius (Hamilton, 1822) (Pisces: Cyprinidae) na zona de amortecimento do Parque Estadual da Serra do Brigadeiro (PESB), Minas Gerais. Biodiversidade Brasileira, v. 3, n. 2, p. 207-216, 2013. Available from: $<$ http://www.icmbio.gov.br/revistaeletronica/ index.php/BioBR/article/view/324>. Viewed: Dec. 17th, 2018.

MARTINS, M. L.; CARDOSO, L.; MARCHIORI, N.; PÁDUA, S. B. Protozoan infections in farmed fish from 
Brazil: diagnosis and pathogenesis. Brazilian Journal of Veterinary Parasitology, v. 24, n. 1, p. 1-20, 2015. doi: 10.1590/S1984-29612015013.

MCDERMOTT, C.; PALMEIRO, B. Selected emerging infectious diseases of ornamental fish. The Veterinary Clinics of North America Exotic Animal Practice, v. 16, n. 2, p. 261-82, 2013. doi: 10.1016/j.cvex.2013.01.006.

MEHRDANA, F.; JENSEN, H.; KANIA, P.; BUCHMANN, K. Import of exotic and zoonotic trematodes (Heterophyidae: Centrocestus sp.) in Xiphophorus maculatus: implications for ornamental fish import control in Europe. Acta Parasitologica, v. 59, n. 2, p. 276-283, 2014. doi: 10.2478/s11686-014-0237-z.

NOGA, E. J. Fish disease: diagnosis and treatment. Iowa: Willey - Blackwell, 2010. 536 p.

PEELER, E. J.; FEIST, S. W. Human intervention in freshwater ecosystems drives disease emergence. Freshwater Biology, v. 56, n. 4, p. 705-716, 2011. doi: 10.1111/j.1365-2427.2011.02572.x.

REED, P.; FRANCIS-FLOYD, R.; KLINGER, R.; PETTY, D. Monogenean parasites of fish. IFAS Extension University of Florida, v. FA-28, 2012. Available from: $<$ https://agrilifecdn.tamu.edu/fisheries/files/2013/09/ Monogenean-Parasites-of-Fish.pdf $>$. Viewed: Dec. 17th, 2018.

ROUBACH, R.; GOMES, L. C.; FONSECA, F. A. L.; VAL, A. L. Eugenol as an efficacious anaesthetic for tambaqui, Colossoma macropomum (Cuvier). Aquaculture Research, v. 36, n. 11, p. 1056-1061, 2005. doi: 10.1111/j.1365-2109.2005.01319.x.

SAHA, M.; BANDYOPADHYAY, P. K. Seasonal incidence of protozoan parasitic infestation in ornamental fishes of West Bengal, India. Journal of Parasitic Diseases, v. 41, n. 2, p. 523-526, 2017. doi: 10.1007/s12639-016-0842-x.

STECKLER, N.; YANONG, R. P. E. Argulus (Fish Louse) infections in fish. IFAS Extension University of Florida, v. FA184, p. 1-4, 2012b. Available from: $<$ http://edis.ifas.ufl.edu/pdffiles/FA/FA18400.pdf>. Viewed: Dec. 17th, 2018.

STECKLER, N.; YANONG, R. P. E. Lernaea (Anchorworm) infestations in fish. IFAS Extension University of Florida, v. FA185, p. 1-4, 2012a. Available from: <http://edis.ifas.ufl.edu/pdffiles/FA/FA18500.pdf $>$. Viewed: Dec. 17th, 2018.

TAVARES-DIAS, M.; LEMOS, J. R. G.; MARTINS, M. L. Parasitic fauna of eight species of ornamental freshwater fish species from the middle Negro River in the Brazilian Amazon Region. Brazilian Journal of Veterinary Parasitology, v. 19, n. 2, p. 103-107, 2010. doi: 10.4322/rbpv.01902007.

THILAKARATNE, I. D. S. I. P.; RAJAPAKSHA, G.; HEWAKOPARA, A.; RAJAPAKSE, R. P. V. J.; FAIZAL, A. C. M. Parasitic infections in freshwater ornamental fish in Sri Lanka. Disease of Aquatic Organisms, v. 54, n. 2, p. 157-162, 2003. doi: 10.3354/dao054157.

VON GERSDORFF JØRGENSEN, L. Infection and immunity against Ichthyophthirius multifiliis in zebrafish (Danio rerio). Fish \& Shellfish Immunology, v. 57, p. 335-339, 2016. doi: 10.1016/j.fsi.2016.08.042.

WHITTINGTON, R. J.; CHONG, R. Global trade in ornamental fish from an Australian perspective: the case for revised import risk analysis and management strategies. Preventive Veterinary Medicine, v. 81, n. 1-3, p. 92-116, 2007. doi: 10.1016/j.prevetmed.2007.04.007. 